\title{
VOICE AND PARTICIPATION OF 'STUDENT CABINET' IN SCHOOL ACTIVITIES THROUGH THE DEVELOPMENT OF 'TEAMWORK': A CASE STUDY OF A GOVERNMENT SECONDARY SCHOOL IN BANGLADESH
}

\author{
Md Khairul Islam*
}

\begin{abstract}
Students' voice and participation in teaching -learning practices in the classrooms and in schools are central in promoting Democratic Citizenship Education (DCE). Aiming to increase the practices of democratic values through education, in 2015 the government of Bangladesh enacted 'student cabinet' in secondary schools in Bangladesh. Through the development of a qualitative case study with an action research component, this study explores how the engagement of 'student cabinet' in school activities could be established through the development of 'teamwork'. Data were collected from the head teacher, two classroom teachers, two group of students and the members of 'student cabinet' using semi-structured interviews, focus group discussions and field notes. Findings suggest that while the 'student cabinet' was not effectively functioning in the school, involvement of its members, the teachers and the head teacher in planning and implementing the activities of the 'student cabinet' through collaborative action research influenced positive changes. 'Strategy of working as a team rather than individuals' showed potentials for improving the engagement of 'student cabinet' in the school activities and developing sense of connectedness with the school community. Findings have implications in promoting DCE through student representative bodies in schools in Bangladesh and other contexts.
\end{abstract}

Keywords: Students' voice and participation, 'student cabinet', 'teamwork', action research, secondary school, Bangladesh.

\section{Introduction and Background of the Study}

Students' voice and participation in the school activities are central in promoting Democratic Citizenship Education (DCE) in schools (Council of Europe, 2010; * Md Khairul Islam, PhD is Associate Professor, Institute of Education and Research
(IER), University of Dhaka, Email: khairulislam@du.ac.bd

Social Science Review [The Dhaka University Studies, Part-D], Vol. 37, No. 2, December 2020 
Osler \& Starkey, 2010). Henderson and Tudball (2016) argue that "since the late 1980s, there has been an increasing focus in many parts of the world on the importance of involving young people in democratic and participatory citizenship" (p.1). It might be an example that "education for democratic citizenship is fundamental to the idea of modern Europe as an integrated and yet culturally diverse area of democratic stability" (Print \& Smith, 2002, p. 103). Scholarly literature of DCE also suggests that understanding democracy and democratic process through education is not enough for DCE since students' engagement in the learning process is essential. For an example, Silman and Caglar (2011) argue that students need "to move beyond conceptual understanding to learning experiences that develop participatory skills and civic dispositions for exercising the rights and carrying out the responsibilities and duties of citizenship in a democracy" (p. 674). Research evidence suggests that DCE in schools has potentials in developing students' knowledge, skills, and attitudes towards the cultivation of democratic culture in the schools and community (Holdsworth \& Jones, 2006; Holdsworth, 2013, 2018; Osler \& Starkey, 2005; 2010).

Constitutionally Bangladesh is a democratic country (Government of the People's Republic of Bangladesh, 1999). "The Constitution of the People's Republic of Bangladesh has been taken into consideration in the formulation of National Education Policy" (Ministry of Education, 2010, p.8). Issues of democratic citizenship have been paid attention in the new education policy. "To show tolerance for different ideologies for the development of a democratic culture and to help develop a life-oriented, realistic and positive outlook" is an example of one of the DCE-focused objectives of education (Ministry of Education, 2010, p. 2). Participatory teaching-learning approaches for DEC, for examples, students' participation in the educational process, fostering creative thinking, and ensuring equal opportunity are explored in the policy.

The secondary school curriculum has been developed in the light of national education policy and it has placed particular importance to "the issue of democratic values aiming to create competent citizens" who will show interest in democracy and be able to practice democracy in future (NCTB, 2012, p.7). Aiming to successful implementation of curriculum and promotion of DCE supportive pedagogies, such as discussion, group-work, role-playing, debate, and question-answer have been included in the curriculum. In addition, the 
Government of Bangladesh enacted 'student cabinet' in secondary schools in Bangladesh as a representative body of general students aiming to practicing and developing democratic values among the students (Directorate of Secondary and Higher Education [DSHE], 2015). This idea is strongly supported by the scholarly literature of DCE (Holdsworth \& Jones, 2006; Osler \& Starkey, 2010; UNESCO/UNICEF, 2007). One of the significant factors identified by Holdsworth and Jones (2006) is 'bonding' among the members of student representative bodies for effective implementation of their activities. They further explain the 'bonding' as working as a team, relationship among the members, and sense of connectedness with school and community.

However, substantial research has not been conducted to examine the activities of 'student cabinet' in schools in Bangladesh. More particularly how the engagement of 'student cabinet' in school activities in Bangladesh could be established through the development of 'teamwork' was apparently unexplored. This research addressed the gap and explored how the engagement of 'student cabinet' in school activities could be established through the development of 'teamwork'.

\section{Conceptualising Students' Voice and Participation for DCE in Schools}

Simply democratic citizenship education means educating students for developing their knowledge, skills and attitudes about democracy as well developing their democratic values through teaching- learning approaches in the classrooms and in the schools. Print and Smith (2002) define DCE as "educating people with new values, conventions and behaviours for living in a democracy" (p. 103). Silman and Kaglar (2011) point out that "students should be taught the elements of democracy and how it works" (p. 674). They also suggest that students need to develop participatory skills and civic dispositions for exercising the rights and duties of citizenship in a democracy. According to Council of Europe (2010) DCE is a combination of concepts and activities, which aims to prepare learners with knowledge, attitudes, and behaviour for the preparation of their democratic life in the society.

The nature of DCE is more focused in practicing democratic values rather than understanding the concept of democracy. Scholarly literature suggests that students' voice and participation are central in promoting DCE in schools (Holdsworth, 2013; 2018; Holdsworth \& Jones, 2006; Osler \& Starkey, 2005; 2010; UNESCO/UNICEF, 2007). Scholars in this area also argue that students' 
voice and participation in school activities significantly depends on the nature of schooling. For examples, Osler and Starkey (2010) point out that "the degree of exercising rights by children and young people in the wider society significantly depends on the ways they experience schooling and on the ways, they experience human rights and democracy in schools" (p.101). Similarly, Roh (2004) states:

Democratic citizenship education in schools can be successful when basic democratic concepts and principles reside at the core of all school programs and school systems themselves are made democratic so that students have opportunities to learn through direct participation in decision-making on matters related to their own concerns and interests as well as through classroom lessons. ( $\mathrm{p} 174)$

The United Nations Convection on the Rights of the Child (UNCRC) (1989) also emphasizes quality education for children and ensuring their voice and participation in the teaching-learning process. It has given an obligation in its article 12(1) that "states parties shall assure to the child who is capable of forming his or her own views the right to express those views freely in all matters affecting the child" (United Nations [UN] General Assembly, 1989, p.4). Based on the analysis of different articles of Convention on the Rights of the Child (CRC), Osler and Starkey (2005) argue that it has valuable pedagogical implications for DCE in the classrooms and in the schools. As an example, they suggest that participation and student's freedom of expression, which needs to be valued in the teaching and learning practices. The recommendations of UNCRC have been clearly reflected in the national education policy and curriculum of Bangladesh (Ministry of Education, 2010). Including other supportive instructions, students' voice and participation are clearly indicated in the education policy (Ministry of Education, 2010) and explored in detail in the curriculum (National Curriculum and Textbook Board [NCTB], 2012). Moreover, recently the government enacted 'student cabinet' in secondary schools where students' voice and participation in the school activities have been focused (DSHE, 2015).

From the analysis of definitions of DCE and relevant literature, it is evident that students' voice and participation in the classroom activities as well as in the school are essential for DCE. It is also apparent that the national education policy and school curriculum of Bangladesh stress on students' direct participation and voice in teaching learning practices. Further measures have been taken for students' voice and participation for improving the practices of democratic values 
through student representative body named 'student cabinet'. This research particularly focused on students' voice and participation for DCE in schools through 'student cabinet'.

\section{Student's Voice and Participation through Student Representative Bodies}

Substantial scholarly literature of DCE suggests that students' voice and participation in school activities can be established through their direct participation in the teaching learning process as well as through the student representative bodies (Holdsworth, 2013; 2018; Holdsworth \& Jones, 2006; Osler \& Starkey, 2010; UNESCO/UNICEF, 2007). Osler and Starkey (2010) argue that "pupil voice refers to children's expressions of their opinions in school, and these may be made directly, or through a representative body, such as a student council" (p.105). Similarly, Holdsworth and Jones (2006) argue that students' participation and their voice in school activities can be achieved through the activities of student action team what is defined by them as "a group of students who identify and work, preferably as part of their curriculum, on a real issue of community interest" (p. 8). They add that through the student action team, students can work for real decision making and action around the issues related to common goods and wellbeing of the school community, which have significant link to formal curriculum goals. Similar to the idea of Holdsworth and Jones' (2006) student action team, UNESCO/UNICEF (2007) argues for DCE through the idea of "children's government" (p. 80). UNESCO/UNICEF supports its idea in the following ways:

Governments, non-governmental organizations and other partners, teachers, parents, and students themselves seek schools in which children learn, schools that are safe, clean, enriching, fair, gender-sensitive, inclusive, child-centered and community-based. Children's governments have been successful in transforming schools into exactly these things, and it is mainly through the active participation of the students that these changes have been possible. While children are often asked in school to sit down, quiet down and settle down, a children's government encourages children to stand up, speak up and take action. (p. 80)

In terms of students' involvement in school activities, UNESCO/UNICEF (2007) points out that "Children's governments work to improve many different aspects of school and community life, such as education, health, protection, water and AIDS awareness. Activities include tutoring, initiating dialogue with teachers, 
holding awareness-raising campaigns, improving the school's physical environment, and practising good hygiene" (p. 81).

Recently the idea of students' voice and participation in school activities through student representative bodies has been initiated through the development of 'student cabinet' in secondary schools in Bangladesh (DSHE, 2015). One of the objectives of developing 'student cabinet' is practicing and developing values of democracy among students and increasing their engagement in different school activities (DSHE, 2015). According to the 'student cabinet' manual (DSHE, 2015), schools are advised to hold elections at the beginning of every year for eight members through the direct voting of students in the schools. It is also reported in the manual that school environment; health; sports, culture, and co-curricular activities; water resources; tree plantation and gardening; celebration of different days and program; reception and entertainment are major areas of involvement of the cabinet (DSHE, 2015).

Development of 'teamwork' is recognised as one of the potential factors for student representative bodies for their effective involvement in school activities (Gollob, Krapf, Olafsdottir, \& Weidinger, 2010; Holdsworth, 2013; 2018; Holdsworth \& Jones, 2006; UNESCO/UNICEF, 2007). Gollob et al. (2010) argue that for the cultivation of democratic values in schools, students need to work together for the common good of school community. Holdsworth and Jones (2006) refer 'teamwork' as way of developing 'bonding' among the members and sense of connectedness with school and community. UNESCO/UNICEF (2007) argues that student representative bodies provide opportunity for building sense of team spirit through their engagement in school activities as a team. Though the 'student cabinet' manual mentions the areas of Cabinet's engagement in secondary schools in Bangladesh, substantial research has not been conducted to understand or develop 'teamwork' in schools. This research examined how the 'student cabinet' was functioning as a team in a government secondary school in Bangladesh and how this could be further developed through action research.

\section{Methodology}

This research aims to investigate the existing status of 'teamwork' and establish voice and participation of 'student cabinet' in a case study school through the development of 'teamwork'. It was situated within the socially critical paradigm (Macdonald, Kirk, Metzler, Nilges, Schempp, \& Wright, 2002). Hatch (2002) 
notes that "an exposition of methodological theory places the proposed study in a research paradigm" (p. 38). As a socially critical research, the purpose of this inquiry was to understand the existing status and challenge the status of 'student cabinet' through the development of 'teamwork' (Macdonald et al., 2002) using collaborative action research.

A qualitative a case study approach was used to conduct this research with an action research component as the nature of this research was to focus on a deep analysis of the particular 'student cabinet' in a particular government secondary school, in a particular place at a particular time (Stake, 1995; Yin, 2009).

It has already stated that as a socially critical researcher my intention was not only investigate the existing status of 'student cabinet' in the case study school but also challenge the status of cabinet through the development of 'teamwork'. Considering the changes in practice through this research, an action research component was used as part of this case study to involve participants in developing new practices. According to Bradbury and Reason (2003), "the core concern for action researchers is to develop practical as well as conceptual contributions by doing research with, rather than on people" (p. 156). Action research is appropriate in this context as "it provides an opportunity for educators to reflect their own practices" (Creswell, 2012, p. 577) and to engage in cycles of planning, and reflection on planning and practice. Guy Wamba (2010) notes that "action research go beyond the notion that theory can inform practice, to the recognition that theory can and should be generated through practice" (p. 171). Moreover, Bargal (2008) points out that action research promotes practices of democratic values, which is relevant with this study. This action research was participatory and collaborative since a collaboration was developed with the school and then participants engaged in the cycles of action research (Cahill, 2007). The stages of planning, implementing, acting, and reflecting as prescribed by Mertler (2006).

Patton (2002) argues that "qualitative inquiry typically focuses in depth on relatively small samples, even single cases $(N=1)$, selected purposefully" (p. 230). He also adds that the nature of the sample in qualitative research depends on the nature and purpose of the study. Moreover, Patton (2002) notes that purposeful strategies are followed for qualitative sample selection rather than methodological rules. Thomas (2011) argues that case study research does not 
require sampling, "it's a choice, a selection" (p. 62) that is meaningfully relevant for my study.

A government secondary school situated at the centre of Dhaka was selected considering some purposes. Since it is a government secondary school, the new initiative for DCE through 'student cabinet' was being implemented there. The head teacher was willing to participate, so she was selected as a participant. The two classroom teachers invited to participate who were interested to work for the development of 'student cabinet' and develop their professional learning in this area. After receiving confirmation from the head teacher and two classroom teachers about their participation in this study, the student-participants were selected purposively. One group of students was selected from Beauty's (pseudonym) class (grade 9) and another group of six students from Shumi's (pseudonym) class (grade 7). These two groups were selected to understand their existing views about the 'teamwork' of 'student cabinet' and their views upon the development of 'teamwork'. Finally, the members of 'student cabinet' were selected for this research. Six out of eight cabinet members joined as participants since two were absent due to their public examinations. It is important to point out that two groups of students from grade 9 and 7 did not participate in the action research. They just provided their opinion at the beginning of the commencement of action research and after the commencement. The actual participants from the school for the action research were two classroom teachers, the head teachers and six members of 'student cabinet'. Though the head teacher was not able to attend all the planning meetings of action research, she shared her thoughts with us and provided regular reflections on planned activities.

Semi-structured interviews, focus group discussions, observations and field notes were used to collect data. The approach of thematic analysis of qualitative data was used through the categorisation by codes (Glesne, 2016). To triangulate the reliability of data, more than two data sources were used (i.e., interviews, focus group discussions, and observations) for data analysis aiming to answer same research question (Oliver-Hoyo \& Allen, 2006). During the analysis and presentation of data, pseudonyms were used for the classroom teachers and the head teacher to address ethical consideration. Number was used for the general students and the members of the 'student cabinet', for example, G9S3 indicates student from grade 9 group and his/her serial number was three; CM4 means one of the cabinet members whose serial number was four. 


\section{Findings and Discussion}

Understanding the existing 'teamwork' of 'student cabinet' in the case study school

According to Capobianco and Feldman (2006) "action research needs to be grounded in what is already known" (p. 499), so it was important for me to understand how the 'student cabinet' was functioning as a team before the action research. Findings indicated that 'student cabinet' was not functioning well as a team in the case study school. Though the head teacher Reba (pseudonym) said that she tried to engage them in activities, both classroom teachers, both group of students, and the members of 'student cabinet' confirmed complete absence of activities as team in the school. For examples, one student from grade 7 said, "I voted for election of 'student cabinet' but I do not know them all. Actually, I did not see them together in the school". Another student from grade 9 said, "Though the 'student cabinet' was elected last year, I have not seen them doing anything meaningful in the school". When the cabinet members were asked, "According to the 'student cabinet' principles, you have to meet once in a month. Did you meet how many times during last few months?" One of them replied, "We never met together as student cabinet". The rest of the members confirmed the opinion. Both classroom teachers, Beauty and Shumi, made similar argument as they never noticed meaningful 'teamwork' of 'student cabinet' or team meeting. Overall, as a team, voice, and participation of 'student cabinet' was apparently absent in the case study school though their voice and participation are central in promoting DCE in schools (Holdsworth, 2013; 2018; Holdsworth \& Jones, 2006; Osler \& Starkey, 2005; 2010; UNESCO/UNICEF, 2007). 'Teamwork' which is recognised as one of the potential factors for their effective involvement in school activities was not well established in the school.

Osler and Starkey (2010) argue that "in order for young people to claim their right to express a view on matters which may affect them at school, teachers and school principals need to provide a space or opportunity for them to do so" (p. 105). Similarly, according to the Department of Education and Science, UK (2002) "the role of the school Principal is of central importance in the establishment and operation of a Student Council" (p. 10). The "student cabinet' manual clearly explains the role of the teachers and the head teachers for the implementation of 'student cabinet' activities (DSHE, 2015) and additionally mentions that the head teachers will take initiative for the involvement of 'student cabinet'. Findings indicated that neither the head teacher nor the classroom 
teachers took initiative for the development of 'teamwork' of the cabinet. For examples, one of the members said, "we did not get opportunity to discuss any issue with the head teacher or the classroom teachers. They never called us or gave us opportunity to share something". Including other members of the cabinet, both classroom teachers supported this argument. However, both classroom teachers committed that upon the development of their further professional learning about 'student cabinet' and initiative from the head teacher they would love to work for the development of 'student cabinet' as a team and increase their meaningful involvement in the school activities. The head teacher showed strong interest for the development of 'student cabinet' in the school through the development of their 'teamwork'. Their commitments were meaningfully reflected during the action research, which is discussed in the following sections.

Engagement of Cabinet in Planned Activities and the Development of 'Teamwork'

It is already discussed that the 'student cabinet' was not functioning well as a team and the school authority did not take any initiative for the development of their 'teamwork'. As a part of action research, classroom teacher Beauty, Shumi, the head teacher discussed together how cabinet members could be involved in different activities as a team. Following the scholarly literature, the importance of working as team by the cabinet in the school was explained. Following the 'student cabinet' manual (DSHE, 2015), the role of the head teacher and the teachers for enacting 'student cabinet' in schools was also explained. Based on the very positive discussion, all agreed to engage the members of the cabinet in different planned activities to establish their 'teamwork' in the school. Following the decision of first collaborative meeting, after one day, another meeting was organised with the team (all members) of 'student cabinet'. The activities and procedures were discussed. It was explained that after the implementation of every planed activity, "we would meet together, and you would be invited to give reflections". Mertler (2006) points out that reflection is "the act of critically exploring what you are doing, why you decided to do it and what its effects have been" (p. 10). Findings indicated that active involvement of the members of 'student cabinet' in the collaborative action research as a team and their engagement in different planned activities potentially influenced their voice and participation in the school activities.

It was a very positive signal while during the first planning meeting all cabinet members were found very excited to present themselves together in a meeting. 
They were also happy and excited as they were invited to talk, and initiative was taken for their involvement. For example, one cabinet member said, "We are very happy as you take initiative for us. In the past, no one took initiative". One planned activity was 'meeting between the all-cabinet members and the head teacher' in every fifteen days. It was decided that the cabinet members would identify problems, discuss in their team, and then discuss with the head teacher. They were also advised to take help from their respective class teachers. It was also decided that cabinet members would have access to the head teacher at any time during school hours for any significant reason.

As decided, the head teacher ensured the practices. The members of 'student cabinet' used to meet regularly with the head teacher. For an example, one day, it was observed that the head teacher was discussing about the upcoming annual sports and prize giving ceremony of the school. She asked cabinet members for their opinion to organize a successful event. The cabinet members provided some useful suggestions, which were well accepted by the head teacher. For examples, all cabinet members recommended to make the playground more suitable for the event since it was rocky and dusty. They also recommended about their roles during the prize giving ceremony where one of the higher administrative authority from the DSHE visited the school. The cabinet also proposed to wear their badges and move together to maintain discipline during the event.

After ending the meeting, the head teacher was impressed by their opinions and proposal for involvement in the event. She was really surprised by the suggestions of cabinet. She said, "I never expected this kind of valuable suggestions from the cabinet. Their suggestions are much matured and supportive to the students' wellbeing and school's positive impression". Similarly, the cabinet members argued that they never thought about their opinion having much importance by the head teacher. They added that having opportunity to express their opinion and acknowledgement from the head teacher increased their confidence and motivation for further involvement in the school activities.

Another planned activity was moving together as a team during the tiffin period and creating environmental awareness among the students since all participants in this study agreed to pay attention to the issue. As a part of creating awareness, all cabinet members began to move together during tiffin period. They used to move around the whole school complex including playground. If they noticed anyone 
committing environmental pollution by throwing different things, they instantly advised them to stop. They also advised the students to use specific bin. Another strategy was motivational speeches from 'student cabinet' during the students' assembly. It was a regular short speech for five minutes by one of the cabinet members focusing the update of school environment and further motivation. Though one of the members used to deliver the speech, the full team of cabinet came to the front and stood together. Generally, the head teacher or Beauty as an assigned teacher coordinated the activity. Though the cabinet members developed every individual speech, concerned teacher approved it before presenting to the students. According to my field note, one of the speeches from a cabinet member was as follows:

Dear friends! You know that our school environment is not good. Particularly our washrooms remain dirty. Do you think who are responsible for this? Who comes from outside? Actually, nobody comes from outside. We are responsible for this since we make it dirty and we do not clean properly. It is not possible for the school authority to keep clean our washroom if we do not want. Please keep our washrooms and school environment clean.

Observations based on the instant evidence of improvement of school environment, both strategies were perceived by Beauty, Shumi, and the head teacher and cabinet members effective and they acknowledged the influences of their 'teamwork'. The improvement was mostly visible during the tiffin period. Since it was very common seeing the students throwing different things on the floor and field, after the beginning of the ongoing strategy of creating awareness, it became very uncommon. All members of cabinet were found confident and happy for making their contributions very visible to school community, as an example of working for common good. Findings also suggest the potentialities of collaborative action research since the change was brought through the initiative of collaborative action research. One example from the comments of 'student cabinet' members on the initiative through action research is:

There was no initiator in the school to engage us in the activities. This is the main reason behind our failure to work as a team. Teachers and the head teacher did not pay attention to the activities of cabinet and we were not serious. You have taken initiatives and our teachers have been motivated including the head teacher. Now they have realized the importance of 'student cabinet' through your initiatives. 
However, without cooperation from the teachers and the head teacher (Osler and Starkey, 2010), both the successful collaboration (Warrican, 2006) and creating change in the school were not possible.

Therefore, it can be argued that when the members of 'student cabinet' had opportunity to work together for the school community and expressed their views on matters, which have impacts on their lives and others in the school, they could meaningfully contribute. The collaborative action research created the opportunity to get involved in the process as a team and developed their 'teamwork'.

\section{Potentials of working together as a team rather than individual members}

In the previous section, it has been discussed how the members of the 'student cabinet' were involved in the collaborative action research as a team and how their voice and participation were ensured in planning, implementing, and reflecting the planned activities in the school. This section discusses how the member of the 'student cabinet' perceived the benefits of working as team rather than individuals. Comments from the students, classroom teachers and the head teacher were also included. Overall findings reflect the potentials of 'teamwork' and support the literature (Gollob et al., 2010; Holdsworth, 2013; 2018; Holdsworth \& Jones, 2006; UNESCO/UNICEF, 2007). In addition, findings indicated that how opportunity to work together during action research influenced the understanding of the cabinet members, the teachers, and the head teacher about the potentials of 'teamwork'. All cabinet members agreed that working as a team changed their mindset and undoubtedly motivated them to get involved as a team and work for the school community. When the cabinet members were asked to reflect on their 'teamwork', they responded that:

CM1: I understand that as a 'student cabinet' member, if I want to do something alone, nobody will value it. We need to work together.

CM2: It is a very good initiative for us to work together. Many students did not know us as cabinet members. This is an opportunity for them to know us and share their views with us.

CM3: The head teachers paid attention to us as we worked together. In the past, she did not pay attention. For an example, one day I went to meet with head teacher to discuss some problems, but she did not pay attention to me. 
Just tell me to discuss with class teachers. The situation has been changed. It is good for us.

CM4: I understand that if we will move alone, students will not give importance to our opinion. If we will move together, they will give more importance.

CM5: Sir, there is a sentence in English that unity is strength. It is very easy to break down a stick, but it is very difficult to break down a bunch of sticks. When we moved together, generally the students paid more attention to us as well as showed their respect to us. We were confident and solved some problems easily as we were in a group. For example, if students make quarrel, we can solve it easily.

CM6: I can give you an example. Normally during the tiffin period, many students used to create indiscipline. Last few days, we moved together around the school during tiffin period and we noticed a range of indiscipline reduced.

The head teacher also provided her final reflection during the post-action research interview:

I want to say that it was a very positive initiative. Probably the members of cabinet realised that they are only six students who were representing about 600 students in the school. They also realised that they needed to do something together for the wellbeing of students. Previously general students did not pay attention to the cabinet and their opinion, but the situation has been changed. General students know that they are different, and they have been elected as cabinet. It is also important for both the students and the members of the cabinet.

During the post action research FGDs, both group of students from grade 7 and 9 provided similar reflections. For examples, one student from grade 7 said, "Now I know who the cabinet members are". Another student from grade 9 said, "I noticed that the members of 'student cabinet' began to work for the school". My observation was very similar with the participants. However, there was a different observation. The progress and establishment of 'teamwork' by the 'student cabinet' in the school was highly visible in comparison with the past, but it was understood that the development was still far away from the recommendation of scholarly global literature of 'teamwork' and student representative bodies. It was not possible to go for further development due the time constraint. 


\section{Conclusion}

It can be concluded that while the 'student cabinet' was not well functioning at the commencement of this study, well-planned collaborative action research that included voice and participation of the members of 'student cabinet' enabled to establish their voice and participation in the school. While prior to action research the cabinet members never met together, all of them used to meet regularly and involved in different activities during the three months action research. Their active involvement in the collaboration potentially influenced their engagement in the school activities. Their regular meeting as cabinet members, getting involvement in planned activities as a cabinet, and having opportunity to provide reflections developed their understanding about the potentialities of 'teamwork' and skills for accelerating the activities and engagement of 'student cabinet' in the school with commitment and confidence. It also indicates that voice and participation of 'student cabinet' in school activities depended on how they could work as a team, and how they could work as team depended on how the school provided them opportunity. Apparently, strategy of "working as a team rather than individuals' showed potentials for improving the engagement of 'student cabinet' in the school activities and developing sense of connectedness with the school community.

Though the findings showed positive outcomes of collaborative action research in a case study school, it was not possible to avoid some challenges and limitations. For examples, it was not possible to ensure the sustainability of the progress of the 'student cabinet' since the collaboration was developed for three months. Another challenge is associated with methodological approach. Being a qualitative case study, findings of this research are not generalizable. However, the procedures of the research and the findings provide examples, which have implications in promoting democratic citizenship education through the student representative bodies like 'student cabinet' in schools in Bangladesh and other contexts.

\section{References}

Bargal, D. (2008). Action research: A paradigm for achieving social change. Small Group Research, 39(1), 17-27.

Bradbury, H., \& Reason, P. (2003). Action research an opportunity for revitalizing research purpose and practices. Qualitative social work, 2(2), 155-175.

Cahill, C. (2007). The personal is political: Developing new subjectivities through participatory action research. Gender, place, and culture, 14(3), 267-292. 
Capobianco, B. M., \& Feldman, A. (2006). Promoting quality for teacher action research: Lessons learned from science teachers' action research. Educational Action Research, 14(4), 497-512.

Council of Europe. (2010). Council of Europe Charter on Education for Democratic Citizenship Directorate of Education and Languages and Human Rights Education. Retrieved from https://rm.coe.int/16803034e5_(Accessed on May 20,2017)

Creswell, J. W. (2012). Educational Research: Planning Conducting and Evaluating Quantitative and Qualitative Research (4th Ed.). Boston: Pearson.

Department of Education and Science, UK. (2002). Student councils: a voice for students. UK: Department of Education and Science.

Directorate of Secondary and Higher Education (DSHE), Ministry of Education, Bangladesh. (2015). Student Cabinet Manual. Dhaka: Ministry of Education.

Glesne, C. (2016). Becoming qualitative researchers: An introduction (5th Ed.). New York, USA: Longman Pub Group.

Gollob, R., Krapf, P., Olafsdottir, O., \& Weidinger, W. (2010). Educating For democracy: Background materials on democratic citizenship and human rights education for teachers. In R. Gollob, P. Krapf \& W. Weidinger (Eds.), (Vol. EDC/HRE Volume I). Belgium: Council of Europe Publishing.

Government of the People's Republic of Bangladesh. (1999). The Constitution of the People's Republic of Bangladesh. Dhaka: Bangladesh Government Press.

Guy Wamba, N. (2010). Developing an alternative epistemology of practice: Teachers' action research as critical pedagogy. Action Research, 9(2), 162-178. doi: 10.1177/14767 50310388054

Hatch, J. A. (2002). Doing qualitative research in education settings. Albany: State University of New York Press.

Henderson, D., \& Tudball, E. (2016). Democratic and participatory citizenship: youth action for sustainability in Australia, Asian Education and Development Studies, 5 (1), 5-19. doi: 10.1108/AEDS-06-2015-0028

Holdsworth, R. (2013). Student participation in school leadership. Teacher Learning Network (TLN) Journal, 20(2), 26-27.

Holdsworth, R. (2018, February). Student voice, agency, participation, Connect, 229, 22-25. Retrieved from https://research.acer.edu.au/cgi/viewcontent.cgi?article=1239\&context= connect (Accessed on January 20, 2019)

Holdsworth, R., \& Jones, G. (2006). What Are Student Action Teams? In R. Holdsworth (Ed.), Student Action Teams: Implementing Productive Practices in Primary and Secondary School Classrooms (pp. 7-10). Australia: Connect Publication.

Macdonald, D., Kirk, D., Metzler, M., Nilges, L. M., Schempp, P., \& Wright, J. (2002). It is all very well, in theory: Theoretical perspectives and their applications in contemporary pedagogical research. Quest, 54(2), 133-156. doi: 10.1080/00336297.2002.10491771

Mertler, C. A. (2006). Action Research: Teachers are Researchers in the Classroom. Thousand Oaks, London \& New Delhi: SAGE.

Ministry of Education. (2010). The National Education Policy. Dhaka: Ministry of Education.

National Curriculum and Textbook Board. (2012). Jatio Shikkhacrom [National Curriculum]. Dhaka: National Curriculum and Textbook Board. 
Oliver-Hoyo, M., \& Allen, D. (2006). The use of triangulation methods in qualitative educational research. Journal of College Science Teaching, 35(4), 42-47.

Osler, A., \& Starkey, H. (2005). Changing Citizenship: Democracy and Inclusion in Education. England: Open University Press.

Osler, A., \& Starkey, H. (2010). Teachers and Human Rights Education. Stoke on Trent, UK \& Sterling, USA: Trentham Books.

Patton, M. Q. (2002). Qualitative research and evaluation methods (3rd ed.). Thousand Oaks, London, \& New Delhi: Sage.

Print, M., \& Smith, A. (2002). Challenges for citizenship education in the new Europe. European Journal of Education, 37(2), 102-105.

Roh, Y. R. (2004). Democratic citizenship education in the information age: a comparative study of South Korea and Australia. Asia Pacific Education Review, 5(2), 167-177.

Stake, R. (1995). The art of case study research. Thousand Oaks: Sage Publications.

Thomas, G. (2011). How to do Your Case Study: A guide for students and researchers. London: Sage

UNESCO/UNICEF. (2007). A Human Rights-Based Approach to Education for All. Paris \& New York: UNESCO \& UNICEF. Retrieved from https://unesdoc.unesco.org/ark:/48223/ pf0000154861 (Accessed on May 9, 2018)

United Nations General Assembly. (1989). Convention on the Rights of the Child. United Nations, Treaty Series, vol. 1577, p. 3.

Yin, R. K. (2009). Case Study Research Design and Methods (4th ed.). Thousand Oaks: SAGE. 